\title{
Role of Electronic Accounting Information Systems in Reducing the Phenomenon of Tax Evasion in Facilities Subject to Income and Sales Tax in the Hashemite Kingdom of Jordan
}

\author{
Reem Oqab Hussein Al- Khasawneh \\ Assoc. Prof. \\ E-mail: Medoheart2000@yahoo.com
}

Received: April 24, 2020

Accepted: May 27, 2020

Published: June 30, 2020

doi:10.5296/ijafr.v10i2.17298

URL: https://doi.org/10.5296/ijafr.v10i2.17298

\begin{abstract}
The study aimed at identifying the role of e-accounting information systems in reducing tax evasion in term of its three stages inputs, processing and outputs. It also explained the role of a compatibility between e-accounting systems and the instructions and procedures of income tax authority for reducing tax evasion. For achieving the purposes of the study, a questionnaire was distributed to employees of tax evasion authority, income and sales tax inspectors. The study found that using e-accounting information systems in the facilities subject to income and sales tax has contributed to a very high degree at input stage whereas the contribution of using e-accounting systems has been high at processing and output stages. In addition, the study indicated that existing the compatibility between e-accounting systems and the instructions of income and sales tax authority has highly contributed to the reduction of tax evasion. It also illustrated that the procedures and methods of professional examination of e-accounting information systems developed by income and sales tax authority have contributed to a very high degree of the reduction of tax evasion. Moreover, the study found that a sufficient experience of employees of income and sales tax authority in the field of using e-accounting information systems has contributed to a very high degree of the reduction of spreading of the phenomenon of tax evasion.
\end{abstract}

Keywords: Tax evasion, E-accounting information systems, Income and sales tax 


\section{Introduction}

Tax is a financial method which public authorities use in order to achieve their public purposes; in some countries such as Jordan, tax is a primary source from which the funds required for public expenses are drawn. However, some taxpayers do not like paying taxes. That is because they do not understand the importance of taxes as a main source for paying off state's expenditures. Tax evasion is an important worthy research topic because it is a deep -rooted problem causing a great harm to national economy and contributing to the decline of the revenues of a public budget; furthermore, it causes other damages affecting the sovereignty and prestige of state and the social and cultural life.

In the light of the widespread of using accurate and quick electronic systems in implementing the accounting processing of business facilities, taxpayers become able to change and amend financial processes subject to income and sales tax authority, thereby occurring tax evasion. Here, tax collectors and income and sales tax authority play a vital role in the reduction of the risks of data misrepresentation and modification, but rather they take an advantage of these systems and software in order to reduce tax evasion.

Hence, the study touches upon the role of electronic accounting systems in reducing the spreading of the tax evasion and examines the mechanisms and controls of e-accounting systems which do not allow companies to manipulate these systems; it also illustrates the control over the use of these electronic technologies in calculating the tax due.

\subsection{Problem of Study}

The phenomenon of tax evasion is one of serious problems the income and sales tax authority in Jordan faces; tax evasion has negative effects such as a lack of cash receipts from which basic current expenditures of Jordanian government are paid. Consequently, a deficit of financing these expenses may occur and the government resorts to borrow in order to pay these expenses. In the long run, tax evasion may obstruct some public services and prejudice the fairness of tax among taxpayers. The problem of study, therefore, is to answer the following questions:

- Does using e-accounting information systems in accounting data input in the facilities subject to tax contribute to the reduction of tax evasion in Jordan?

- Does using e-accounting information systems in accounting data processing in the facilities subject to tax contribute to the reduction of tax evasion in Jordan?

- Does using e-accounting information systems in accounting data output in the facilities subject to tax contribute to the reduction of tax evasion in Jordan?

- Is there a compatibility between e-accounting systems used in the facilities subject to the tax and the instructions issued by income and sales tax authority in order to reduce tax evasion?

- Do the employees of income and sales tax authority have a sufficient experience of using e-accounting information systems contributing to the reduction of spreading of 


\section{Macrothink \\ International Journal of Accounting and Financial Reporting

the phenomenon of tax evasion?

- Does income and sales tax authority develop the procedures and methods of professional examination of e-accounting information systems used in the facilities subject to income and sales tax in a manner that contributes to the reduction of spreading the phenomenon of tax evasion in Jordan.

\subsection{Purposes of Study}

The study aims at:

- Identifying to which extent e-accounting information systems contribute to the reduction of the phenomenon of tax evasion in the facilities subject to income and sales tax in Jordan;

- Indicating that using e-information systems in making tax decisions in the facilities subject to income and sales tax in Jordan contributes to the reduction of tax evasion;

- Identifying the most important controls, standards and conditions of e-accounting information systems in the facilities subject to income and sales tax in Jordan which contribute to the reduction of tax evasion; and

- Identifying the procedures and methods followed by the employees of income and sales tax authority in order to detect the tax evasion in the facilities subject to income and sales tax in Jordan.

\subsection{Importance of Study}

The study is important because its topic is significant; the importance of the study can be summarized as follows:

- Tax evasion has become a public phenomenon which must be studied in the light of using e-accounting systems in processing and making tax decisions taken in the facilities subject to income and sales tax in Jordan;

- Tax is a basic financial resource for a country and using electronic systems in the facilities subject to income and sales tax becomes important. Thus, this study illustrates the advantages and disadvantages of these systems used in tax calculation in the facilities subject to income and sales tax in Jordan;

- Using e-information system in data processing in the facilities subject to income and sales tax in Jordan is important since it reduces tax evasion; and

- Using e-information system in making tax decisions in the facilities subject to income and sales tax in Jordan is important since it reduces tax evasion

\subsection{Hypotheses of Study}

The study tests the following hypotheses:

- Using e-accounting information systems in accounting data input in the facilities 


\section{MlMacrothink}

International Journal of Accounting and Financial Reporting

subject to tax contributes to the reduction of tax evasion in Jordan;

- Using e-accounting information systems in accounting data processing in the facilities subject to tax contributes to the reduction of tax evasion in Jordan;

- Using e-accounting information systems in accounting data output in the facilities subject to tax contributes to the reduction of tax evasion in Jordan;

- The compatibility between e-accounting systems used in the facilities subject to the tax and the instructions issued by income and sales tax authority contributes to the reduction of tax evasion;

- the procedures and methods of professional examination of e-accounting information systems developed by income and sales tax authority in order to be used in the facilities subject to income and sales tax contribute to the reduction of spreading the phenomenon of tax evasion in Jordan; and

- A sufficient experience of using e-accounting information systems, which the employees of income and sales tax authority have, contributes to the reduction of spreading the phenomenon of tax evasion.

\section{Theoretical Framework and Previous Studies}

\subsection{Previous Studies}

- Masadeh, Mosa's study (2014) aimed at identifying the efficiency of accounting information announced by Jordanian Joint-stock companies in the light of using computerized accounting information systems. A researcher used an approach based on primary data in order to develop a questionnaire; 120 questionnaires were distributed. The study found that computerized accounting information systems have been used in Jordanian joint-stock companies, and they have been characterized by an efficiency. The study recommended that employees shall be trained for using e-accounting programs which are easy and accurate.

- Jadallah Mohammad Fahd's study (2011) was to identify the efficiency of tax information in joint-stock companies listed in Palestine Securities Exchange in the light of using computerized accounting information systems. The researcher developed study research tool composed of 65 paragraphs. The questionnaire was distributed to a research sample which consisted of 80 respondents. After collecting, the questionnaires were coded and statistically processed using statistical package for social sciences (SPSS). The study indicated that its questions were highly approved; its main question of the study has been as follows: 'to which extent tax information in public joint-stock companies listed in Palestine securities exchange is efficient in the light of using computerized accounting information systems?'. The study found that there are statistically significant differences at a level of significance $(\alpha=05.0)$ in term of the efficiency of information tax in joint-stock companies listed in Palestine securities exchange; the variables have been age, academic specialization, years of experience, job designation. 


\section{$\Lambda$ Macrothink}

International Journal of Accounting and Financial Reporting ISSN 2162-3082 2020, Vol. 10, No. 2

- Attia's study (2008) aimed to highlight the important role of accounting information systems in solving tax calculation problems. The researcher used an analytical descriptive approach; the study was conducted in Egypt and it found that using accounting information systems in Egyptian tax authority has contributed to the achievement of the quality of technical and administrative performance in Egyptian tax authority. In addition, the study showed that using the theory of accounting information systems has led to the emergence of taxpayer who trusts in the performance of Egyptian tax authority. As a result, he/she pays willingly the taxes. The study recommended that further studies on this topic shall be conducted and training required for examining the accounting information system environment, in which tax authority works, shall be held.

- Al-Husseini's study (2007) aimed at identifying to which extent joint stock company has accounting systems. It also was to illustrate the quality of accounting information provided by these systems. In addition, the study aimed to identify to which extent tax authority examines control methods of accounting programs; it also illustrated their impact on estimation process. An analytical descriptive approach was used; and the secondary resources such as books, periodicals and reports issued by tax authority were used in order to build the theoretical framework; a questionnaire and personal interviews were used for collecting a primary data. The study was conducted on 658 Palestinian joint-stock companies; questionnaire was distributed to 63 tax inspectors. The study found that accounting information provided by accounting systems has no credibility; and protected accounting programs used by business facilities have controlling defects. In addition, the study showed that control methods have not been tested by tax authority and accountants have not adhered to the rules of professional conduct. The study concluded that panel law shall be applied to the accountants helping their client evade the taxes. It also concluded that tax authority shall have effective control methods; accounting programs used in the companies shall be licensed by governmental authorities; in addition, business facilities shall register accounting programs in income tax authority.

- Al-Dais's study (2008) aimed at identifying to which extent accounting information system used in tax authority in Yemen has the characteristics recognized by studies and researches of accounting information systems. The study showed that this information can be used for making various administrative decisions which reduce highly the phenomenon of tax evasion. It also illustrated that accounting information system used by tax authority in Yemen does not provide the requirements of administrative, accounting and tax controls contributing highly to the reduction of tax evasion. Accounting information system used by tax authority in Yemen also does not take advantage of non- financial information which contributes essentially to the reduction of tax evasion.

This study is distinguished because it touches upon the role of e-accounting system in reducing tax evasion in the facilities subject to income and sales tax authority in Jordan; it also identifies the gaps of e-accounting systems which can be exploited by the facilities 


\section{MlMacrothink}

International Journal of Accounting and Financial Reporting

subject to income and sales tax in order to evade the tax. In addition, the study showed that income and sales tax authority can play an important role in reducing tax evasion through controlling and supervising e-accounting system developed in taxable facilities.

\subsection{Theoretical Framework}

\subsubsection{Concept and Goals of Tax}

Tax is an important resource of state's revenues and budget which covers public expenditures. Tax system has been evolved because the roles played by the country have developed; tax is no longer limited to financial purpose i.e feeding public treasury, but rather it aims at achieving social and economic goals such as redistribution of income among society's segments, investment encouragement, implementation of projects desired by the country (Al-Hajj Mosa, 1998). Accordingly, tax becomes a tool of social and economic plan since it is one of effective tools of financial and economic policies.

Jurists, thinkers and economists differed in the definition of tax because of the development of economic, social and political thought. It was defined as 'a financial deduction from individual's wealth performed by the country in order to achieve a public goal. (Abu-Hashish, 2004); it was also defined as 'an amount of money paid forcibly by individuals, whether they are natural persons or legal entities, to the country in order to cover public expenses (Al-Shawarbi, 1997).

\subsubsection{Concept of Tax Evasion}

In science of finance, various definitions of tax evasion were mentioned; Wahba (2010) defined tax evasion as 'an avoidance of paying deliberately a part of or all taxes due and taxpayers evade taxes before a payment period begins or during the period which payment must be made through using illegal means.' Al-khatib (2000) defined tax evasion as 'avoidance of paying part or whole of tax without transferring its burden to others so that country revenues will be affected and its rights will be wasted.' Income and sales tax authority defined tax evasion in income tax law (Income tax law 2018) as 'using fraudulent methods involving cheating, falsification and forgery or providing deliberately a false information in order to avoid paying part or whole taxes or to reduce them.'

According to the point of view of the researcher, tax evasion through electronic systems is a crime committed by the taxpayer, either natural person or legal entity, through a violation of the rules of tax law whether by falsifying or concealing information or providing incorrect electronic information or using electronic means in order to avoid paying the tax or reduce the tax owed by the taxpayer; thus, the taxpayer evades the tax burden, imposed by tax law.

\subsubsection{Forms and Methods of Electronic Tax Evasion}

Some taxpayers use the expertise in order to find a defect or gap in legal text or use legal or illegal method which helps evade or reduce the taxes. The researchers in the field of tax evasion have provided various images of tax evader. Wahba (2010) mentioned some of images of tax evasion as follows: 


\section{Macrothink}

International Journal of Accounting and Financial Reporting

ISSN 2162-3082

- Taxpayer fails to disclose the total economic activity so that no information related to the size of economic activity is submitted to income and sales tax authority, thereby evading the tax due. Thus, due taxes are not paid or are reduced. Here, electronic systems can be used; these systems can electronically process the data and provide unreal data on the reality of organization's business; in addition, a computer technician or information technology specialist who knows these systems can delete or hide some relevant operations and files.

- Electronic system can hide some data; and no trace of data amendment can be found; then, taxpayers can conceal the real size of business in their data.

- Taxpayer increases the expenses and decreases the revenues; then, the costs are imaginarily inflated through increasing the cost of goods and employees' wages. Consequently, apparent profits decrease. To achieve these processes, electronic systems can be used for processing the data; and these systems can conceal these revenues and invoices can be issued particularly at the end of fiscal year. Thus, tax payment can be carried over to next year.

- Sale prices of goods and services decrease; and import papers and invoices can be forged. So that, a number of imported materials appears to be low, and then importer can evade customs duties.

\subsubsection{Electronic Accounting Information Systems and Tax Evasion}

Romney and Steinbart (2006) have pointed out the types of fraud of accounting information systems; there are various methods of tax evasion as the following:

- Theft, unauthorized use, modification and copying of data, and destruction of programs and data are methods used for evading the taxes.

- Electronic systems can be designed in order to allow to evade the taxes and commit cybercrimes.

2.2.4.1 Role of E-Accounting Systems in Reducing Tax Evasion and Instructions of Income and Sales Tax Authority

Using e-accounting information systems provides an environment which helps taxpayer evade the tax. However, control authorities depend on control mechanisms which reduce tax evasion. In addition, the employees of income and sales tax authority are trained in order to test and evaluate e-accounting systems used in the facilities. In this section of study, the role of e-accounting information systems in reducing tax evasion is illustrated. In addition, the instructions of income and sales tax authority regarding tax evasion are stated.

2.2.4.2 Role of Accounting Information Systems in Reducing Tax Evasion in Stage of Data input

Data input is one of the most important stages of electronic information system in which data can be manipulated. A set of controls shall be provided in e-accounting information system in order to reduce tax evasion. For example, movements are not performed twice; invoices and 
documents shall be numbered in serial number so that if administration cancels the movement, the system will show it. The instructions of income and sales tax authority indicated that an annual serial number of sale invoices shall necessarily be provided in electronic accounting information systems. Furthermore, original documents related to paper-based financial operations shall be kept by the facility.

2.2.4.3 Role of Accounting Information Systems in Reducing Tax Evasion in Stage of Data processing

The researcher believes that accounting systems shall have the controls which allow to processes the data in a manner that prevents tax evasion; the system shall ensure that all installed records are migrated; in addition, account tree shall be built in a manner ensuring that all invoices and records are not transferred to incorrect accounts, so that, taxable amounts can be concealed. Moreover, records and movements shall be renumbered. When designing, electronic accounting system shall have controls preventing the deletion of transaction after it has been entered. The instructions of income and sales tax authority indicated that electronic accounting information system must not allow to amend, change or delete the items of entered data after they have been migrated. In addition, data migration shall be conducted within one day from the date of data entry. Furthermore, all entry movements shall be associated with a user name according to specific powers assigned; a table shall be created in system database which contains a record of amendments; a screen shall be customized in order to view these amendments and filter the data. In addition, an electronic link between warehouse system and accounting system of purchasing and selling operations including fixed and mobile points of sales shall be available; database shall be only managed by the authority which has prepared the system. Furthermore, a certificate proving that the data has not been deleted or amended by a party outside the company shall be provided.

2.2.4.4 Role of Accounting Information Systems in Reducing Tax Evasion in Stage of Data output

Electronic accounting information system provides a set of controls reducing tax evasion. For example, the system saves daily closing reports, and extracts backup copies of data each two weeks in order to be saved in external storage units; a prior written approval shall be obtained from income and sales tax authority when backup copies of data are retrieved; and a process of data retrieval shall be conducted by a party who has prepared the system. In addition, it shall keep a special record documenting retrieval processes. Furthermore, income and sales tax authority indicated that essential reports shall be prepared; the reports include the following: reports on deposits, withdrawals, credits and points of sales, Z report, $\mathrm{X}$ report, Trial report, and period sales report.

2.2.5 Procedures of Income and Sale Tax Authority Ensuring That Electronic Accounting Systems Are Not Exploited for Tax Evasion

Income and sales tax Authority has developed a set of procedures aiming to limit the use of information technology in tax evasion as follows:

- An approval shall be taken from income and sales tax authority if the facilities subject 


\section{Ml Macrothink}

International Journal of Accounting and Financial Reporting

to income and sales tax develop electronic system;

- Income and sales tax Authority shall be provided with a copy of documentation of program and database and user manual within 30 days from the date of preparing the system;

- Tax income and sales tax authority shall be provided with a list of names of clients for whom computerized accounting systems were prepared before the end of third month of each year;

- No amendment to the system or program used by taxpayer's employees shall be conducted unless a prior written approval is obtained from income and sales tax authority; and a pledge made according to the form prepared by the authority shall be submitted; and

- A permanent committee shall be formed by general manager of income and sales tax authority whose its duties will be as follows:

- The committee examines taxpayer's computerized accounting system in order to identify to which extent it is compliant with the principles and conditions of approving the computerized accounting records and documents;

- The committee performs the examination mentioned in item 1 on its own initiative or upon the request of the concerned auditor; and

- The committee shall keep all required documents and information.

The system shall provide a record called modification log when the facility subject to income and sales tax makes the modification; the modification log includes the following:

- Modification movements of the records including date, hour and items modified;

- Previous vales;

- Current vales;

- Reason of modification; and

- Name and symbol of user who performs input movements.

\section{Methodology of Study}

\subsection{Methods of Data Collection}

To achieve the purposes of study, an analytical descriptive approach has been used. In addition, deductive approach has been used in order to test the hypotheses. Likert five-point scale has been used to answer questionnaire questions; this scale uses 5. Strongly agree, 4. Agree, 3. Neither agree nor disagree, 2. Disagree and 1.strongly disagree.

To explain the results, a range (1-1.79) indicates that there is no significant effect; the range (1.8-2.59) indicates that the degree of importance of item is low; the rang (2.60-3.39) indicates that the degree of importance of item is medium; the range (3.40-4.19) indicates that 


\section{Mll Macrothink}

International Journal of Accounting and Financial Reporting

ISSN 2162-3082

2020, Vol. 10, No. 2

the degree of the importance of item is high; the range (4.20-5) indicates that the degree of the importance of item very high. A statistical package for social studies (SPSS), percentages and arithmetic means have been used for analysing the data.

\subsubsection{Population and Sample of Study}

Population of study consists of tax inspectors and assessors employed in income and sales tax authority. For the purposes of study, a random sample of 70 employees of income and sales tax authorities in Amman and Irbid has been chosen; this sample has been divided into two sections; (1) sample of 50 tax inspectors and assessors of income and sales tax authorities in Amman and Jordan, and (2) sample of 20 employees working in tax evasion section in income and sales tax authorities. A questionnaire has been distributed to the employees; Total number of retrieved questionnaires has reached $65 ; 5$ questionnaires have been excluded because they are invalid for analysing. Thus, response rate of questionnaires distributed to tax inspectors and assessors and employees of tax evasion section is $85 \%$.

\subsection{Reliability of Study Tool}

Cronbach's alpha coefficient has been used for testing internal reliability of questionnaire axes and statements; Table 1 outlines Cronbach's alpha coefficients; the percentages have been considered appropriate for analysing study's variables and testing the hypotheses.

Table 1. Coefficients of reliability (Cronbach's Alpha coefficient)

\begin{tabular}{|c|c|c|c|}
\hline Results & & & Axis \\
\hline Results & Alph Coefficient & $\begin{array}{l}\text { Number } \\
\text { statements }\end{array}$ & \\
\hline High & 94 & 8 & $\begin{array}{l}\text { Role of e-accounting information } \\
\text { systems in reducing tax evasion in the } \\
\text { stage of data input }\end{array}$ \\
\hline High & 91 & 7 & $\begin{array}{l}\text { Role of accounting information } \\
\text { systems in reducing tax evasion in the } \\
\text { stage of data processing }\end{array}$ \\
\hline High & 92 & 9 & $\begin{array}{l}\text { Role of accounting information } \\
\text { systems in reducing tax evasion in the } \\
\text { stage of data output }\end{array}$ \\
\hline High & 94 & 8 & $\begin{array}{l}\text { the compatibility between electronic } \\
\text { accounting systems used in the } \\
\text { facilities subject to income and sales } \\
\text { tax and the instructions issued by } \\
\text { income and sales tax authority }\end{array}$ \\
\hline High & 91 & 6 & $\begin{array}{l}\text { Cognitive skills and sufficient } \\
\text { experience the employees of income } \\
\text { and sales tax authority possess in } \\
\text { order to use e-accounting information } \\
\text { systems }\end{array}$ \\
\hline High & 92 & 9 & $\begin{array}{l}\text { Procedures and methods applied in } \\
\text { income and sales tax authority in } \\
\text { order to reduce tax evasion }\end{array}$ \\
\hline
\end{tabular}




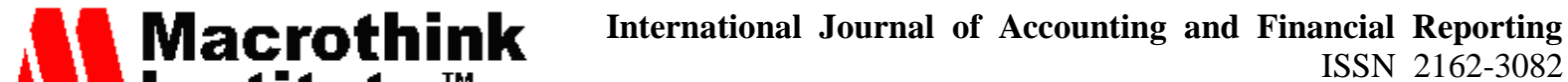 2020, Vol. 10, No. 2}

\subsection{Data Analysis and Hypothesis Testing}

\subsubsection{First Hypothesis Testing}

To validate this hypothesis, arithmetic means and standard deviations of statements related to first hypothesis have been extracted. Table 2 illustrates the results.

Table 2. Arithmetic means and standard deviations of Statements related to first hypothesis listed in a descending order

\begin{tabular}{|c|c|c|c|c|}
\hline $\begin{array}{c}\text { Answer } \\
\text { Orientation }\end{array}$ & Standard Deviation & $\begin{array}{c}\text { Arithmetic } \\
\text { mean }\end{array}$ & Statements & No. \\
\hline \multicolumn{5}{|c|}{ Following statements measure the contribution of using electrical accounting information systems to reduce tax evasion } \\
\hline Extremely high & .645 & 4.27 & $\begin{array}{c}\text { Electronic accounting systems have no } \\
\text { ability to amend accounting documents } \\
\text { and records }\end{array}$ & 1 \\
\hline Extremely high & .658 & 4.27 & $\begin{array}{c}\text { E-accounting system does not allow to } \\
\text { enter the invoice, which has the same } \\
\text { number, twice }\end{array}$ & 2 \\
\hline Extremely high & .693 & 4.20 & $\begin{array}{l}\text { The system does not allow to enter the } \\
\text { same data more than once }\end{array}$ & 3 \\
\hline Extremely high & .710 & 4.20 & $\begin{array}{l}\text { The system does not have a feature } \\
\text { which allows to delete some records or } \\
\text { invoices without leaving a trace of data }\end{array}$ & 4 \\
\hline High & .702 & 4.19 & $\begin{array}{l}\text { E-accounting information system does } \\
\text { not provide an ability of deleting the } \\
\text { records or documents }\end{array}$ & 5 \\
\hline Extremely high & .674 & 4.20 & $\begin{array}{l}\text { The system does not allow to enter the } \\
\text { same data at same time }\end{array}$ & 6 \\
\hline Extremely high & .714 & 4.22 & $\begin{array}{c}\text { E-accounting system does not allow the } \\
\text { accountant to number manually sales } \\
\text { invoices }\end{array}$ & 7 \\
\hline Extremely high & .742 & 4.20 & $\begin{array}{l}\text { E-accounting information system does } \\
\text { not allow to make more than one } \\
\text { sequence of sales numbers as the } \\
\text { accountant deems appropriate }\end{array}$ & 8 \\
\hline Extremely high & .742 & 4.25 & $\begin{array}{c}\text { The system does not allow to modify the } \\
\text { values of invoice after it has been entered } \\
\text { unless an approval is obtained }\end{array}$ & 9 \\
\hline Extremely high & .69 & 4.22 & & Total \\
\hline
\end{tabular}

Table 2 shows arithmetic means and standard deviations of statements of first hypothesis; the arithmetic means have ranged between 2.27 - 4.19. Accordingly, responses' orientation has indicated that using e-accounting information system in entering the data contributes to an extremely high degree of the reduction of tax evasion through an existence of a set of controls organizing the process of data entry.

In addition, arithmetic means of the statements which form first hypothesis have been compared with standard mark 3 - hypothesis acceptance standard- by using t-test as stated in Table 3. 


\section{Ml Macrothink}

International Journal of Accounting and Financial Reporting

ISSN 2162-3082

2020, Vol. 10, No. 2

Table 3. Arithmetic means, standard deviations and T-test of statements which form first hypothesis

\begin{tabular}{cccccc}
\hline $\begin{array}{c}\text { Statistical } \\
\text { Significance }\end{array}$ & T-Value & $\begin{array}{c}\text { Standard } \\
\text { Deviation }\end{array}$ & $\begin{array}{c}\text { Arithmetic } \\
\text { Mean }\end{array}$ & Number & \\
\hline 000. & 190.72 & 69. & 4.22 & 65 & $\begin{array}{l}\text { Role of e-accounting information systems in } \\
\text { reducing tax evasion in the stage of data } \\
\text { input }\end{array}$ \\
\hline
\end{tabular}

Table 3 has indicated that there are statistical differences at $(\alpha=0.05)$ between arithmetic mean and standard deviation 3; statistical significance has been 0.000 . Thus, the hypothesis has been accepted.

\subsubsection{Second Hypothesis Testing}

To validate this hypothesis, arithmetic means and standard deviations of Statements related to second hypothesis have been extracted. Table 4 illustrates the results.

Table 4. Arithmetic means and standard deviations of Statements related to Second hypothesis listed in a descending order

\begin{tabular}{|c|c|c|c|c|}
\hline $\begin{array}{l}\text { Answer } \\
\text { Orientation }\end{array}$ & Standard Deviation & $\begin{array}{l}\text { Arithmetic } \\
\text { mean }\end{array}$ & Statements & No. \\
\hline \multicolumn{5}{|c|}{$\begin{array}{c}\text { Following statements measure the contribution of e-accounting systems to the reduction of tax evasion at the stage of data } \\
\text { processing }\end{array}$} \\
\hline High & .690 & 4.19 & $\begin{array}{l}\text { the data on the financial operations shall } \\
\text { be migrated within one day from the date } \\
\text { of its entry }\end{array}$ & 1 \\
\hline High & .706 & 4.15 & $\begin{array}{l}\text { e-accounting information system can } \\
\text { renumber the records and movements }\end{array}$ & 2 \\
\hline High & .741 & 4.15 & $\begin{array}{l}\text { A mechanism of data processing in the } \\
\text { system provides the ability to modify the } \\
\text { data so that sales invoices of certain } \\
\text { client can be migrated to total account } \\
\text { receivable }\end{array}$ & 3 \\
\hline High & .735 & 4.12 & $\begin{array}{l}\text { e-accounting information system does } \\
\text { not allow to modify, amend or delete the } \\
\text { entered data after it has been migrated }\end{array}$ & 4 \\
\hline High & .666 & 4.10 & $\begin{array}{l}\text { E-accounting information system does } \\
\text { not allow to build account tree in a } \\
\text { manner that leads to migrate invoices } \\
\text { and records to incorrect accounts. }\end{array}$ & 5 \\
\hline High & .679 & 4.10 & $\begin{array}{l}\text { All input movements are associated with } \\
\text { user name according to the powers } \\
\text { assigned }\end{array}$ & 6 \\
\hline High & .732 & 4.05 & $\begin{array}{l}\text { A certificate proving that the data is not } \\
\text { deleted or modified by a party outside } \\
\text { the company shall be provided to tax } \\
\text { authorities }\end{array}$ & 7 \\
\hline High & .706 & 4.12 & Total & \\
\hline
\end{tabular}




\section{Ml Macrothink}

International Journal of Accounting and Financial Reporting

ISSN 2162-3082

2020, Vol. 10, No. 2

Table 4 shows arithmetic means and standard deviations of statements of second hypothesis; the arithmetic means have ranged between 4.19 - 4.05. Total arithmetic mean has been 4.12. Accordingly, responses' orientation has indicated that using e-accounting information system contributes highly to the reduction of tax evasion.

In addition, arithmetic means of the statements which form second hypothesis have been compared with standard mark 3 - hypothesis acceptance standard- by using t-test as stated in Table 5.

Table 5. Arithmetic Means, Standard Deviations and T-test of Statements which form second Hypothesis

\begin{tabular}{ccccccc}
\hline $\begin{array}{c}\text { Statistical } \\
\text { Significance }\end{array}$ & T-Value & $\begin{array}{c}\text { Standard } \\
\text { Deviation }\end{array}$ & $\begin{array}{c}\text { Arithmetic } \\
\text { Mean }\end{array}$ & Number & \\
\hline 000. & 143.31 & 706. & 4.12 & 65 & $\begin{array}{l}\text { The contribution of data processing in } \\
\text { e-accounting information system to the } \\
\text { reduction of tax evasion }\end{array}$ \\
\hline
\end{tabular}

Table 5 has indicated that there are statistical differences at) $\alpha \mathrm{d}$ ( 0.05 between arithmetic mean and standard deviation 3; the results have indicated that there are statistical differences between the procedures and controls of e-accounting information systems used in the facilities subject to income and sales tax authority and the reduction of tax evasion in Jordan . Thus, the hypothesis has been accepted.

\subsubsection{Third Hypothesis Testing}

To validate this hypothesis, arithmetic means and standard deviations of Statements related to third hypothesis have been extracted. Table 6 illustrates the results.

Table 6. Arithmetic means and standard deviations of statements related to third hypothesis listed in a descending order

\begin{tabular}{cccc}
\hline Answer & Standard Deviation & $\begin{array}{c}\text { Arithmetic } \\
\text { mean }\end{array}$ & Statements \\
Orientation & & No.
\end{tabular}

Following statements measures the contribution of e-accounting information system to the reduction of tax evasion at the stage of data output

\begin{tabular}{|c|c|c|c|c|}
\hline High & .648 & 4.18 & $\begin{array}{l}\text { E-accounting information system } \\
\text { provides an ability to modify the design } \\
\text { and form of data outputs such as sale } \\
\text { invoice and reports in a manner that } \\
\text { some essential data such as operator } \\
\text { number or taxpayer name cannot be } \\
\text { appeared }\end{array}$ & 1 \\
\hline High & .651 & 4.18 & Daily closing reports are kept & 2 \\
\hline High & .756 & 4.09 & $\begin{array}{l}\text { Backup copies of data are extracted once } \\
\text { every two weeks }\end{array}$ & 3 \\
\hline High & .716 & 3.99 & Copies are saved in external storage units & 4 \\
\hline High & .654 & 3.97 & $\begin{array}{l}\text { A prior written approval shall be } \\
\text { obtained from income and sales tax } \\
\text { authority when backup copies are }\end{array}$ & 5 \\
\hline
\end{tabular}




\section{II Macrothink}

International Journal of Accounting and Financial Reporting

ISSN 2162-3082

2020, Vol. 10, No. 2

\begin{tabular}{cccl}
\hline High & 673 & retrieved. \\
\hline High & .747 & $\begin{array}{l}\text { It is ensured that a company maintains a } \\
\text { special record documenting retrieval } \\
\text { processes. }\end{array}$ \\
\hline High & 3.93 & $\begin{array}{l}\text { It is ensured that companies subject to } \\
\text { income and sales tax authority extract the } \\
\text { required reports. }\end{array}$ \\
\hline High & 3.93 & $\begin{array}{l}\text { The system does not allow to modify the } \\
\text { form of the reports so that the data } \\
\text { cannot be deleted or modified. }\end{array}$ \\
\hline High & .784 & $\begin{array}{l}\text { E-accounting information system does } \\
\text { not provide the ability to modify the data } \\
\text { of sales invoices before and after } \\
\text { printing. }\end{array}$ \\
\hline
\end{tabular}

Table 6 shows arithmetic means and standard deviations of statements of third hypothesis which measures the contribution of e-accounting information system to the reduction of tax evasion in the stage of data output. The arithmetic means have ranged between 3.92-4.18. Accordingly, responses' orientation has indicated that e-accounting information system used in extracting the data contributes highly to the reduction of tax evasion.

In addition, arithmetic means of the statements which form third hypothesis have been compared with standard mark 3 - hypothesis acceptance standard- by using t-test as stated in Table 7.

Table 7. Arithmetic means, standard deviations and T-test of statements which form third hypothesis

\begin{tabular}{|c|c|c|c|c|c|}
\hline $\begin{array}{c}\text { Statistical } \\
\text { Significance }\end{array}$ & T-Value & $\begin{array}{l}\text { Standard } \\
\text { Deviation }\end{array}$ & $\begin{array}{c}\text { Arithmetic } \\
\text { Mean }\end{array}$ & Number & \\
\hline .000 & 134.4 & 0.728 & 4.017 & 65 & $\begin{array}{l}\text { The contribution of data output in } \\
\text { e-accounting information system to the } \\
\text { reduction of tax evasion }\end{array}$ \\
\hline
\end{tabular}

Table 7 has indicated that there are statistical differences at ( $\alpha d 0.05)$ between arithmetic mean and standard deviation 3 ; the results have indicated that there are statistical differences between the procedures and controls of e-accounting information systems used in the facilities subject to income and sales tax authority and the reduction of tax evasion in Jordan. Thus, the hypothesis has been accepted.

\subsubsection{Fourth Hypothesis Testing}

To validate this hypothesis, arithmetic means and standard deviations of Statements related to fourth hypothesis have been extracted. Table 8 illustrates the results. 


\section{MIN Macrothink}

International Journal of Accounting and Financial Reporting

ISSN 2162-3082

2020, Vol. 10, No. 2

Table 8. Arithmetic means and standard deviations of Statements related to fourth hypothesis listed in a descending order

\begin{tabular}{cccc}
\hline Answer & Standard Deviation & Arithmetic & Statements \\
Orientation & mean & & No. \\
\hline
\end{tabular}

Following statements measure the compatibility between accounting systems used in the facilities subject to the tax and the instructions issued by income and sales tax authority in order to reduce tax evasion,

\begin{tabular}{|c|c|c|c|c|}
\hline Very high & .645 & 4.27 & $\begin{array}{l}\text { E-accounting information system and its } \\
\text { specifications are registered by income } \\
\text { and sales tax authority }\end{array}$ & 1 \\
\hline Very high & .693 & 4.20 & $\begin{array}{l}\text { An approval shall be taken from income } \\
\text { and sales tax authority if e-accounting } \\
\text { information system is developed by the } \\
\text { facilities subject to income and sales tax. }\end{array}$ & 2 \\
\hline High & .710 & 4.18 & $\begin{array}{l}\text { e-accounting information system } \\
\text { provides all books, documents and } \\
\text { reports required by tax law }\end{array}$ & 3 \\
\hline High & .702 & 4.17 & $\begin{array}{l}\text { An approval shall be taken from income } \\
\text { and sales tax authority if e-accounting } \\
\text { information system is modified by the } \\
\text { facilities subject to income and sales tax. }\end{array}$ & 4 \\
\hline High & .859 & 4.13 & $\begin{array}{l}\text { It is required that the system provides the } \\
\text { information covering all activities } \\
\text { subject to income and sales tax. }\end{array}$ & 5 \\
\hline High & .668 & 4.13 & $\begin{array}{l}\text { It is ensured that all necessary } \\
\text { information including taxpayer name, tax } \\
\text { number and address, are printed on all } \\
\text { documents and publications of } \\
\text { e-accounting system }\end{array}$ & 6 \\
\hline High & .742 & 4.17 & $\begin{array}{l}\text { A computerized accounting information } \\
\text { system of taxpayer is examined in order } \\
\text { to ensure to which extent taxpayer is } \\
\text { compliant with the principles and } \\
\text { conditions of approving computerized } \\
\text { accounting documents and records }\end{array}$ & 7 \\
\hline High & .784 & 3.92 & $\begin{array}{l}\text { It is ensured that the facility subject to } \\
\text { income and sale tax has a modification } \\
\text { log which includes modification } \\
\text { movements of records, current and } \\
\text { previous values and the reason of } \\
\text { modification, name and code of user who } \\
\text { made entry movements. }\end{array}$ & 8 \\
\hline High & .73 & 4.15 & Total & \\
\hline
\end{tabular}

Table 8 shows arithmetic means and standard deviations of statements of fourth hypothesis. The arithmetic means have ranged between $3.92-4.27$. It is noted that the facilities subject to income and sales tax cannot create or enter e-accounting system unless an approval is obtained from income and sales tax authority; in addition, tax authority must ensure that the system is compatible with tax requirements. Accordingly, responses' orientation agrees highly with income and sales tax authority that an approval shall be obtained when e-accounting information system is created and registered. Furthermore, the orientation of the rest 


\section{Al Macrothink}

International Journal of Accounting and Financial Reporting

ISSN 2162-3082

2020, Vol. 10, No. 2

responses of statements agrees highly with tax authority that e-accounting information system shall be compatible with the requirements of income and sales tax authority.

In addition, arithmetic means of the statements which form fourth hypothesis have been compared with standard mark 3 - hypothesis acceptance standard- by using t-test as stated in Table 9.

Table 9. Arithmetic means, standard deviations and T-test of statements which form fourth hypothesis

\begin{tabular}{ccccccc}
\hline $\begin{array}{c}\text { Statistical } \\
\text { Significance }\end{array}$ & T-Value & $\begin{array}{c}\text { Standard } \\
\text { Deviation }\end{array}$ & $\begin{array}{c}\text { Arithmetic } \\
\text { Mean }\end{array}$ & Number & \\
\hline .000 & 126.33 & 73. & 4.15 & 65 & $\begin{array}{c}\text { The compatibility between e-accounting } \\
\text { information system and the instructions of } \\
\text { income and sales tax authority }\end{array}$ \\
\hline
\end{tabular}

Table 9 has indicated that there are statistical differences at ( $\alpha d 0.05)$ between arithmetic mean and standard deviation 3; the results have indicated that there is a compatibility between e-accounting information systems and the requirements and instructions of income and sales tax authority in Jordan and the reduction of tax evasion. Thus, the hypothesis has been accepted.

\subsubsection{Fifth Hypothesis Testing}

To validate this hypothesis, arithmetic means and standard deviations of Statements related to fifth hypothesis have been extracted;. Table 10 illustrates the results.

Table 10. Arithmetic means and standard deviations of statements related to fifth hypothesis

\begin{tabular}{|c|c|c|c|c|}
\hline $\begin{array}{c}\text { Answer } \\
\text { Orientation }\end{array}$ & Standard Deviation & $\begin{array}{l}\text { Arithmetic } \\
\text { mean }\end{array}$ & Statements & No. \\
\hline \multicolumn{5}{|c|}{$\begin{array}{l}\text { Following statements measure to which extent the procedures and methods of professional examination of e-accounting } \\
\text { information systems in the facilities subject to income and sales tax contribute to the reduction of spreading the } \\
\text { phenomenon of tax evasion. }\end{array}$} \\
\hline Very high & .67 & 4.58 & $\begin{array}{l}\text { It is ensured that no amendment to } \\
\text { accounting records and documents is } \\
\text { performed in a manner that affects a } \\
\text { validity of reports submitted to tax } \\
\text { authority }\end{array}$ & 1 \\
\hline High & .78 & 4.16 & $\begin{array}{l}\text { It is ensured that no deletion of some } \\
\text { records or documents of system is } \\
\text { performed in a manner that affects the } \\
\text { validity of reports submitted to tax } \\
\text { authority }\end{array}$ & 2 \\
\hline High & .78 & 4.42 & $\begin{array}{l}\text { It is ensured that e-accounting } \\
\text { information system issues one copy of } \\
\text { internal documents (as original) such as } \\
\text { sales documents and the rest is as copies. }\end{array}$ & 3 \\
\hline Very high & .65 & 4.22 & $\begin{array}{l}\text { It is ensured that no misrepresentation of } \\
\text { the entered data is performed. }\end{array}$ & 4 \\
\hline
\end{tabular}




\begin{tabular}{|c|c|c|c|c|}
\hline Very high & .68 & 4.54 & $\begin{array}{l}\text { It is ensured that e-accounting } \\
\text { information system gives the internal } \\
\text { documents a serial number }\end{array}$ & 5 \\
\hline High & .71 & 4.14 & $\begin{array}{l}\text { It is ensured that sales invoices issued by } \\
\text { the system include main taxpayer data } \\
\text { such as operator number and taxpayer } \\
\text { name. }\end{array}$ & 6 \\
\hline Very high & .68 & 4.46 & $\begin{array}{l}\text { Documents and invoices are kept after } \\
\text { they have been cancelled and they shall } \\
\text { be stamped by cancelation stamp. }\end{array}$ & 7 \\
\hline Very high & .66 & 4.24 & $\begin{array}{l}\text { It is ensured that after printing, } \\
\text { documents and invoices are cancelled by } \\
\text { a reversing entry }\end{array}$ & 8 \\
\hline High & .84 & 4.16 & $\begin{array}{l}\text { It is ensured that the invoices and } \\
\text { documents cannot be deleted after they } \\
\text { have been printed }\end{array}$ & 9 \\
\hline Very high & .35 & 4.32 & Total & \\
\hline
\end{tabular}

Table 10 shows arithmetic means and standard deviations of statements of fifth hypothesis. The arithmetic means have ranged between $4.14-4.58$; the orientation of response of statements $1,3,4,5,7$, and 8 has indicated that the procedures and methods of professional examination of e-accounting information systems in the facilities subject to income and sales tax contribute to a very high degree of the reduction of spreading the phenomenon of tax evasion, whereas the rest of responses of statements has been high. As a whole, the orientation of the responses has been very high.

In addition, arithmetic means of the statements which form fifth hypothesis have been compared with standard mark 3 - hypothesis acceptance standard- by using t-test as stated in Table 11.

Table 11. Arithmetic means, standard deviations and T-test of statements which form fifth hypothesis

\begin{tabular}{|c|c|c|c|c|c|}
\hline $\begin{array}{c}\text { Statistical } \\
\text { Significance }\end{array}$ & T-Value & $\begin{array}{l}\text { Standard } \\
\text { Deviation }\end{array}$ & $\begin{array}{c}\text { Arithmetic } \\
\text { Mean }\end{array}$ & Number & \\
\hline .000 & 126.883 & 35. & 4.32 & 65 & $\begin{array}{l}\text { Professional examination of e-accounting } \\
\text { information systems used in order to reduce } \\
\text { tax evasion }\end{array}$ \\
\hline
\end{tabular}

Table 11 has indicated that there are statistical differences at $(\alpha=0.05)$ between arithmetic mean and standard deviation 3; statistical significance has been 000; the results have indicated that there is a relationship between professional examination of e-accounting information systems done by income and sales tax authority and the reduction of tax evasion. Thus, the hypothesis has been accepted.

\subsubsection{Sixth Hypothesis Testing}

To validate this hypothesis, arithmetic means and standard deviations of Statements related to sixth hypothesis have been extracted. Table 12 illustrates the results. 


\section{MlMacrothink}

International Journal of Accounting and Financial Reporting

ISSN 2162-3082

2020, Vol. 10, No. 2

Table 12. Arithmetic means and standard deviations of Statements related to sixth hypothesis

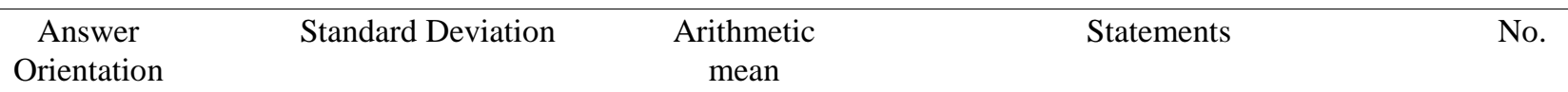

Following statements measure to which extent the cognitive skills and experiences of employees of income and sales tax authority which use in e-accounting information systems contribute to the reduction of spreading of the phenomenon of tax evasion

\begin{tabular}{|c|c|c|c|c|}
\hline Very high & .67 & 4.58 & $\begin{array}{l}\text { Employees of income and sales tax } \\
\text { authority know a working mechanism of } \\
\text { e-accounting information systems use by } \\
\text { the facilities subject to tax }\end{array}$ & 1 \\
\hline High & .78 & 4.16 & $\begin{array}{c}\text { All employees of income and sales tax } \\
\text { authority have an appropriate IT } \\
\text { qualification }\end{array}$ & 2 \\
\hline Very high & .67 & 4.42 & $\begin{array}{l}\text { An appropriate professional qualification } \\
\text { related to potential gaps of e-accounting } \\
\text { systems which may use to tax evasion, is } \\
\text { available }\end{array}$ & 3 \\
\hline High & .65 & 4.16 & $\begin{array}{l}\text { the employees of income and sales tax } \\
\text { authority have a sufficient experience of } \\
\text { using e-accounting information systems }\end{array}$ & 4 \\
\hline Very high & .68 & 4.54 & $\begin{array}{l}\text { Tax administration is continuously } \\
\text { training its employees in order to } \\
\text { develop their capability }\end{array}$ & 5 \\
\hline High & .84 & 4.16 & $\begin{array}{l}\text { Income and sales tax authority keeps up } \\
\text { with all developments of electronic } \\
\text { systems }\end{array}$ & 6 \\
\hline Very high & .35 & 4.34 & Total & \\
\hline
\end{tabular}

Table 12 shows arithmetic means and standard deviations of statements of sixth hypothesis. The arithmetic means have ranged between $4.16-4.58$, the orientation of response of statements 1, 3, and 5 regarding the cognitive skills and experience of e-accounting information systems possessed by the employees of income and sales tax authority have been very high, whereas the rest of responses of statements has been high. As a whole, the orientation of the responses has been very high.

In addition, arithmetic means of the statements which form sixth hypothesis have been compared with standard mark 3 - hypothesis acceptance standard- by using t-test as stated in Table 13.

Table 13. Arithmetic means, standard deviations and T-test of statements which form sixth hypothesis

\begin{tabular}{cccccc}
\hline $\begin{array}{c}\text { Statistical } \\
\text { Significance }\end{array}$ & T-Value & $\begin{array}{c}\text { Standard } \\
\text { Deviation }\end{array}$ & $\begin{array}{c}\text { Arithmetic } \\
\text { Mean }\end{array}$ & Number & \\
\hline .000 & 130.883 & 35. & 4.34 & 65 & $\begin{array}{l}\text { The contribution of Cognitive knowledge } \\
\text { and experience of employees of income and } \\
\text { sales tax authority to the reduction of tax } \\
\text { evasion }\end{array}$ \\
\hline
\end{tabular}




\section{Ml Macrothink}

International Journal of Accounting and Financial Reporting

ISSN 2162-3082

Table 13 has indicated that there are statistical differences at $(\alpha=0.05)$ between arithmetic mean and standard deviation 3; statistical significance has been 000.; the results have indicated that there is a relationship between the cognitive knowledge and experience of employees of income and sales tax authority of using e-accounting systems and the reduction of tax evasion. Thus, the hypothesis has been accepted.

\section{Results and Recommendations}

\subsection{Results}

The study has found the following results:

- Using e-accounting information systems in entering the data in the facilities subject to income and sales tax contributes to a very high degree of the reduction of tax evasion in Jordan;

- Using e-accounting information systems in processing the data in the facilities subject to income and sales tax contributes highly to the reduction of tax evasion in Jordan;

- Using e-accounting information systems in extracting the data in the facilities subject to income and sales tax contributes highly to the reduction of tax evasion in Jordan;

- The existence of compatibility between e-accounting information systems used in the facilities subject to tax and the instructions issued by income and sales tax authority contributes highly to the reduction of tax evasion;

- The procedures and methods of professional examination of e-accounting information systems developed by income and sales tax authority in order to be used in the facilities subject to income and sales tax contribute to a very high degree of the reduction of spreading the phenomenon of tax evasion in Jordan; and

- A sufficient experience of using e-accounting information systems, which the employees of income and sales tax authority possess, contributes to a very high degree of the reduction of spreading the phenomenon of tax evasion.

\subsection{Recommendations}

The study has recommended the following:

- Tax authorities shall examine periodically and suddenly e-accounting information systems; so that it is ensured that no amendment to the system or accounting records has been performed;

- Income and sales tax authority shall request the facilities subject to the tax a report prepared by auditor confirming the integrity and correctness of accounting data processing according to income tax low;

- Tax authorities shall continuously train their employees in order to enhance their professional experience and provide them with an adequate information on the methods of electrical tax evasion; 


\section{Macrothink}

International Journal of Accounting and Financial Reporting

ISSN 2162-3082

- Laws of e-accounting systems used in income and sales authority shall be developed in order to cope with the development of financial systems and the trend towards electronic applications and digital economy; and

- Income and sales tax authority shall use electronic systems in monitoring taxable facilities.

\section{References}

Abu Hashish, K A. (2004). Practical Cases and Applications Of Measuring Taxable Income, Advanced Studies of Tax Accounting (1st ed.). Amman, Dar Al-Hamed for Publishing and Distribution.

Abu Hashish, K. M. (2008). Tax Accounting (1st ed.), p. 64. Dar Al-Athara For Publishing, Amman-Jordan.

Abu Nassar, M. (2011). Tax accounting: Income and Sales Tax (1st ed.), p. 33. AmmanJordan.

Ahmad, B. M. (2006). Role of Accounting Information Systems in Rationalizing Administrative decisions In Palestinian Business Facilities. Master Thesis, Islamic University, Gaza.

Ahmaro, I. H. (2006). Reasons of Weakness of control procedures of Accounting Information Systems. Faculty of Economics and Administrative Sciences, Al-Zarqa Private University.

Al-Batriq, Y. A. O., \& Abdulaziz, S. (2000). Tax Systems: An Introduction to Comparative Analysis. University House, Alexandria, Egypt.

Al-Hussaini, K. (2007). Extent of Reliance on Accounting Information For Estimating Income Tax of Palestinian Companies, Master Thesis, Islamic University, Gaza.

Amended Law of Income Tax Law No. 38 of 2018 (Periods of 2019 and beyond).

Ammurrah, R. (2010). Tax and Tax Evasion. Retrieved from www.tahasoft.com/books/305.docx

Attia, Y. N. (2008). Use of Accounting Information Theory in Eliminating Tax Calculation Problems. Fourteen Conference and Problems of Tax Calculation of Egyptian Tax System.

Dais, F. A. N. (2008). Role of Accounting Information Systems in Reducing Tax Evasion in Tax Authority in the Republic of Yemen. Unpublished Master Thesis, Al AL-Bayt University, Mafraq University, p. 22.

Jihad, M. F. J. (2011). Efficiency of Tax Information In Joint-Stock Company Listed In Palestine Securities Exchange in the Light of Using Computerized Accounting Information Systems. Master Thesis, An-Najah University, Nablus.

Jumah, A., Al-Orbaid, I., \& Al-Zoubi, Z. (2003). Accounting Information Systems: A Contemporary Applied Introduction (1st ed.). Dar Al-Manahj for Publishing and Distribution. 


\section{Ml Macrothink \\ International Journal of Accounting and Financial Reporting \\ ISSN 2162-3082 2020, Vol. 10, No. 2}

Masadeh, M. (2014). Efficiency of Accounting Information Announced by Jordanian Joint-Stock Companies in the Light of Using Computerized Accounting Information Systems and the Point of View of Auditors of Income and sales Tax Authority. Master Thesis, Yarmouk University, Jordan.

Muharram, M. A. M. Building A Model For Tax Control For Reducing Tax Evasion In The Hashemite Kingdom of Jordan: Applied Study of Industrial Sector. Unpublished Master Thesis, Amman Arab University, Amman, Jordan, p. 39.

Qatawneh, A. M. (2008). Tax Accounting (1st ed.), pp. 7-8. Dar Wael For Publishing, Amman-Jordan.

\section{Copyright Disclaimer}

Copyright for this article is retained by the author(s), with first publication rights granted to the journal.

This is an open-access article distributed under the terms and conditions of the Creative Commons Attribution license (http://creativecommons.org/licenses/by/4.0/) 